\title{
Potential of Caatinga forage plants in ruminant feeding
}

\author{
Mércia Virginia Ferreira dos Santos ${ }^{1,3}$, Mário de Andrade Lira ${ }^{2,3}$, José Carlos Batista Dubeux \\ Junior $^{1,3}$, Adriana Guim ${ }^{1,4}$, Alexandre Carneiro Leão de Mello ${ }^{1}$, Márcio Vieira da Cunha ${ }^{5}$ \\ ${ }^{1}$ Departamento de Zootecnia - UFRPE. \\ 2 IPA. \\ 3 Pesquisador CNPq. \\ ${ }^{4}$ Bolsista CAPES \\ 5 UFRPE - UAST.
}

ABSTRACT - Caatinga is the most important biome for the livestock in the Brazilian semi-arid region. This review paper aimed to present information on different forage aspects of caatinga vegetation for ruminant feeding. Caatinga vegetation is formed mainly by shrubs and small trees, usually presenting thorns, deciduous leaves, and leaf abscission occurring frequently at the onset of the dry season. Additional components of the botanical composition in this biome includes the families cactaceae, bromeliaceae, and a herbaceous component formed by grasses, legumes, and forbs, often presenting annual cycle. Quantitative information of caatinga vegetation is scarce in the literature, mainly for the herbaceous stratum. Methodological aspects such as lack of standardization across evaluations make comparison regarding forage potential of caatinga plant species difficult. Index species must be identified within each caatinga type. Quantitative aspects of biological $\mathrm{N}_{2}$ fixation by caatinga species have not been extensively studied. Regarding forage nutritive value, it is necessary to study $\mathrm{N}$ availability for ruminants in caatinga plants, since large proportion of this element may bind to fiber components (ADIN). Manipulation of caatinga vegetation is an alternative to change forage quantity and quality for grazing animals, affecting their performance as a result. Studies measuring qualitative and quantitative variability of native forage resources from caatinga are mandatory in order to improve animal feeding management, with the ultimate goal of creating sustainable animal production based on caatinga vegetation.

Key Words: chemical composition, native plant, quantitative aspect, semi-arid

\section{Potencial de plantas forrageiras da Caatinga na alimentação de ruminantes}

RESUMO - Considerando a importância do bioma Caatinga na pecuária da região semiárida brasileira, o presente trabalho objetivou apresentar informações sobre diferentes aspectos forrageiros de plantas da caatinga, com vistas à alimentação de ruminantes. A vegetação de caatinga é constituída por arbustos e árvores de pequeno porte, geralmente dotados de espinhos, sendo caducifólias, em sua maioria, perdendo suas folhas no início da estação seca. Complementam ainda a composição botânica desse bioma, cactáceas, bromeliáceas e um componente herbáceo, formado por gramíneas e dicotiledôneas, predominantemente anuais. Informações, principalmente sobre o aspecto quantitativo de plantas da caatinga, notadamente para o estrato herbáceo ainda são escassas. Dificuldades e desuniformidade de metodologias de avaliação, além de falta de detalhamento das metodologias utilizadas, dificultam a comparação de resultados quanto ao potencial forrageiro de algumas plantas. A fixação biológica de $\mathrm{N}$ atmosférico por espécies da caatinga até o momento foi pouco estudada, notadamente quanto aos aspectos quantitativos. Faz-se necessária uma avaliação mais profunda sobre a disponibilidade do nitrogênio, uma vez que parte deste pode estar ligado a parede celular (NIDA). A manipulação da caatinga é uma alternativa para modificar a quantidade e qualidade da forragem disponível aos animais, conseqüentemente modificar o desempenho animal. Estudos que mensurem as variações qualitativas e quantitativas das forrageiras nativas da Caatinga são primordiais para o manejo de suplementação alimentar, com vistas à sustentabilidade de produção animal em áreas de Caatinga.

Palavras-chave: aspecto quantitativo, composição química, planta nativa, semiárido

\section{Introduction}

The Brazilian Northeast covers an area of 1,558,196 km² (18.3\% of the total area) with a population of 51,609,027 inhabitants (28.05\% of the Brazilian population), according to IBGE (2007). The semiarid region of

\footnotetext{
Corresponding author:mercia@dz.ufrpe.br
}

Brazil covers 982,563 km² (Brazil, 2005a), with 89.46\% located in the Northeast region, where eight out of nine states have at least $45 \%$ of their area included in the semi-arid.

The Northeast Brazil is characterized by the diversity of landscapes, and the Caatinga stands out as the only 
biome exclusively Brazilian, with an area of $844,453 \mathrm{~km}^{2}$ (IBGE, 2004) fully inserted into the semiarid climate.

Irregular rainfall distribution reduces possibility of annual crops and livestock production is one of the most important options for Northeast Brazil, and the Caatinga is an important forage resource for this region. The agroforestry system is widely practiced in the semiarid region, formed by livestock under extensive grazing on Caatinga vegetation, timber resources exploitation and shifting cultivation with the use of burning techniques for the production of subsistence crops, under or not a spatial or sequential arrangement.

Moreover, Caatinga has low stocking rate, because of seasonal characteristics of plants, adverse conditions of climate and soil, and above all, the vegetation that is mostly composed by non-forage plants. Guimarães Filho et al. (1995) reported values of $12-15$ ha- ${ }^{1} \mathrm{AU}-{ }^{1}$ year- ${ }^{1}$ $(1 \mathrm{AU}=450 \mathrm{~kg}$ animal live weight) for the stocking rate of Caatinga and $6-8 \mathrm{~kg}$ of weight gain- ${ }^{1}$ ha- ${ }^{1}$ year- ${ }^{1}$; when only the rainy season was considered, the stocking rate reached $4-5$ ha- ${ }^{1}$ AU- ${ }^{1}$ year- ${ }^{1}$. With such average stocking rate and a land-tenure structure in which $90 \%$ of rural properties occupy less than 100 ha (IBGE, 1997), an alternative for the farming systems in the semiarid would be to earn productive profits from the land (Moreira et al., 2007). An option would be to feed caatinga plants to the animals during the rainy season when forage is at maximum offer; during the dry season, stockpiled forage from cultivated pasture and preserved forage could be used. This study aimed to evaluate information about different forage characteristics of plants from caatinga on ruminant feeding.

\section{Characterization of Caatinga}

Caatinga vegetation is composed by shrubs and small trees, usually thorny and deciduous, which lose their leaves in early dry season. Annual plants, cacti, bromeliads, and an herbaceous component (composed of grasses and dicotyledons) are further complements to the botanical composition of this biome.

Based on the vegetation $\mathrm{x}$ soil interaction, Caatinga may be divided into the following areas: hyper-xerophytes (34.3\%); hypo-xerophytes (43.2\%); humid islands (9.0\%); “Agreste” and transition area (13.4\%) (Sá et al., 2003).

Density, frequency, and dominance of plant species are phytosociologically determined by changes on topography, soil type, and rainfall. Although 12 types of Caatinga can be physiognomically identified (Andrade-Lima, 1981), and a wide variation of the floristic composition is displayed as a result of human activities, two general models are presented: the shrub-arboreous caatinga that is predominant in the interior semiarid and the arboreous-caatinga which is characterized by watersheds, "pés-de-serra" and alluvium. Livestock activities tend to occupy the shrubarboreous type and the agriculture the arboreous type (Araújo Filho \& Crispim, 2002).

Caatinga has a large number of plant species that varies according to stratum, year, methodology, and human actions, but most surveys refer to shrubs and trees. Caatinga is a mosaic of thorny shrubs and dry seasonal forests, with more than 2,000 species of vascular plants, fish, reptiles, amphibians, birds and mammals. The endemism in these groups ranges from 7 to $57 \%$ in the Caatinga (Leal et al., 2005).

Morphological and quantitative aspects of native plants of Caatinga

Herbage mass of caatinga varies greatly, especially according to the year season, the caatinga type, rainfall, grazing pressure, density, management method, evaluation method, among others.

Plant density is related to the actual herbage mass but the large number of young individuals should also be considered, as reported by Albuquerque et al. (2008), that found $3.38 \mathrm{pl} / \mathrm{m}^{2}$ (height $<0.5 \mathrm{~m}$ ) in caatinga under different grazing intensities. Only part of the plants in caatinga has forage value and some of the produced forage is inaccessible to the animal due to the height of some plants.

At Ouricuri region, Pernambuco state, Lima (1984) worked on three collection sites at three different periods and found about $1,048.4$ and 7,084.4 stems- ${ }^{1}$ ha- $^{1}$ for trees and shrubs, respectively. Andrade et al. (2009) observed herbaceous flora with 3,190 individuals $/ \mathrm{m}^{2}$. Density of species varies greatly according to the type of caatinga, human actions, as well as the method used to enroll the species.

Forage yield is highly variable, and depends on year season, rainfall and evaluation method. According to Araújo Filho \& Crispin (2002), during the rainy season, most forage is provided by the herbaceous stratum, with small percentage of trees and shrubs foliage. However, as the dry season comes, the leaves from woody species become the main forage source for animals. YdoyagaSantana et al. (2010a) reported that herbage mass decreased and botanical composition changed in a caatinga managed by deforestation and enrichment with Buffel grass (Cenchrus ciliaris) and "Corrente" grass (Urochloa trichopus) for more than 20 years (Table 1). The herbaceous component represented a significant proportion of total biomass. Thus, under adequate stocking rate, the 
Table 1 - Herbage mass and botanical composition of Caatinga grazed by cattle in the rainy season, in the municipality of Serra Talhada, Pernambuco state

\begin{tabular}{|c|c|c|c|c|c|}
\hline \multirow[t]{2}{*}{ Component/common } & \multirow[t]{2}{*}{ Scientific name } & \multicolumn{2}{|c|}{ Herbage mass (kg DM/ha) } & \multicolumn{2}{|c|}{ Botanical composition (\% in weight) } \\
\hline & & February & July & February & July \\
\hline \multicolumn{6}{|l|}{ Herbage } \\
\hline Buffel grass & Cenchrus ciliaris L. & 1885 & 196 & 29 & 25 \\
\hline Corrente grass & Urochloa trichopus Stapf & 521 & 54 & 8 & 7 \\
\hline Malva & Pavonia cancelata Cav & 804 & 85 & 13 & 11 \\
\hline Pimenta d’agua & Phyllantus sp & 367 & 42 & 6 & 5 \\
\hline Jitirana & Ipomoea sp & 722 & 72 & 11 & 9 \\
\hline Orelha-de-onça & Macroptilium martii Benth & 225 & 30 & 4 & 4 \\
\hline Other species & & 1930 & 303 & 30 & 39 \\
\hline Total & & 6454 & 782 & 100 & 100 \\
\hline \multicolumn{6}{|l|}{ Tree-shrub } \\
\hline Mororó & Bauhinia cheilantha (Bong.) Steud & 551 & 56 & 14 & 15 \\
\hline Marmeleiro & Croton sonderianus Muell. Arg & 895 & 104 & 25 & 28 \\
\hline Jurema-preta & Mimosa SP & 415 & 41 & 12 & 11 \\
\hline Angico-manso & A. macrocarpa Benth & 143 & 19 & 4 & 5 \\
\hline Imburama & C. leptophloeos (Mart.) Gillett & 170 & 11 & 5 & 3 \\
\hline Pereiro & A. pyrifoluim Mart. & 19 & 3.6 & 1 & 1 \\
\hline Aroeira & M. urundeuva Fr. All. & 87 & 8.2 & 3 & 2 \\
\hline Other species & & 1214 & 135 & 36 & 35 \\
\hline Total & & 3495 & 378 & 100 & 100 \\
\hline
\end{tabular}

Source: adapted from Ydoyaga-Santana et al. (2010a).

significant decreasing production from herbaceous and arboreous-shrub strata in the rainy season might be explained by the reduced rainfall periods and by the fact that most species are deciduous shrubs.

Management methods are useful to increase herbage mass for ruminant feeding in the Caatinga. Araújo Filho et al. (2002) compared the phytomass values from thinned caatinga and lowered caatinga and observed higher shoot phytomass from the herbage stratum in thinned caatinga at the end of the rainy season. Higher phytomass values occurred in years with higher rainfall (Table 2).

Management of thinned caatinga must consider the maintenance of the floristic composition stability in the herbaceous stratum that is easily affected by grazing, mainly with sheep, which graze the forage excessively low due to their grazing behavior. The high selectivity of sheep can virtually eliminate the herbage even when seedlings and then forage yield gets drastically reduced. Thus, sheep grazing thinned Caatinga under continuous stocking rate is

Table 2 - Herbage mass $\left(\mathrm{kg}^{-1} \mathrm{ha}^{-1}\right)$ of the herbaceous stratum of managed caatinga, in the end of rainy season

\begin{tabular}{lccc}
\hline Year/Management & Cutting & Thinning & Mean \\
\hline 1981 & $3,835 \mathrm{Aa}$ & $3,826 \mathrm{Aa}$ & $3,830 \mathrm{a}$ \\
1982 & $2,780 \mathrm{Bb}$ & $3,621 \mathrm{Aa}$ & $3,200 \mathrm{~b}$ \\
1983 & $1,156 \mathrm{Bc}$ & $1,816 \mathrm{Ab}$ & $1,486 \mathrm{c}$ \\
Mean & $2,590 \mathrm{~B}$ & $3,088 \mathrm{~A}$ & - \\
\hline
\end{tabular}

Means followed by the same capital letter within a row and small letter within a column do not differ $(\mathrm{P}>0.05)$ by Tukey test.

Source: adapted from Araújo Filho et al. (2002). absolutely not recommended, and alternative systems should be applied, such as alternating sheep with goats or using a deferred grazing system (Araújo Filho, 2006).

“Capim-de-raiz” (Chloris orthonoton Doell), “Capimmilhã” [Brachiaria plantaginea (Link) Hitchc] and "orelha-de-onça” [Macroptilium martii (Benth.) Maréchal \& Baudet] are native herbaceous species found in Caatinga areas, and "agreste” and "sertão” pastures, in Pernambuco state. These native species constitute important forage source for animal feeding (Table 3) and their percentage in the pasture is affected by the year season and pasture management.

\section{Cultivated Caatinga plants}

Native forages of Caatinga may be used by increasing the percentage of more palatable species, and eliminating the low forage value species, as have been done by the thinning practice. Besides, if an intensified use of a determined species is desired, one or more populations of the species should be managed, which would become a

Table 3 - Dry matter yield of native plants or naturalized from Caatinga

\begin{tabular}{lccc}
\hline $\begin{array}{l}\text { Trait } \\
\text { DM yield } \\
\left(\mathrm{kg}^{-1} \text { ha }^{-1} \text { ) }\right.\end{array}$ & 1,357 & 883.95 & 2,574 \\
$\begin{array}{l}\text { Cutting height } \\
\begin{array}{l}\text { Deferred period } \\
\text { (days) }\end{array}\end{array}$ & 90 & $5 \mathrm{~cm}$ & Ground level \\
$\begin{array}{l}\text { Source } \\
\text { Fernandes et al. } \\
(1983)\end{array}$ & Assis (1992) & Silva (2010) \\
\hline
\end{tabular}


domesticated population. Furthermore, a deep knowledge about the species is needed, especially concerned with the more appropriate spreading techniques, management, diseases, pests, and genetics.

The cultivation of native species of caatinga is an important alternative to increase the fodder supply, particularly because the plants are ecologically adapted. However, cultivated native plants of Caatinga will probably present more problems such as pests and diseases than the ones grown with the diversity and the natural biological control of the original ecosystem.

Initiatives for the cultivation of some native species of caatinga considered the variation of dry matter yield for each plant species (Table 4). Several researches available in literature fail to describe important information, such as the plant age and tillage system, making the comparison of the results difficult.

Alencar (2006) collected "Sabiá" specimens that had branches with diameter d" $10 \mathrm{~mm}$ and observed an average annual yield of $2.0 \mathrm{t} \mathrm{DM}^{-1} \mathrm{ha}^{-1}$, considering 187 trees- $^{1}$ ha- $^{1}$. Moreover, Caldas et al. (2010) observed that the grazing forage yield of "Sabiá" species was not affected by year season (Table 5), which is probably associated to the level of residual moisture in the soil caused by an atypical rainy season that kept plants with leaves and branches up to $5 \mathrm{~mm}$ during the dry season months.

Silva et al. (2007) evaluated the "Xiquexique" and "Mandacaru" cactus behavior, propagated by cuttings, in the "Seridó" microregion, Rio Grande do Norte state (Table 6), and found low levels of forage yield.

\section{Propagation of native plants from Caatinga}

Plant propagation process is important to evaluate the potential of native species of Caatinga. The thornless
"Sabiá" is recommended to be used as forage because the absence of thorns provides higher animal intake and fewer injuries of animals and handlers. Vegetative propagation technique ensures that characteristics of a plant are copied exactly as the original one.

In works carried out with different substrates, a low percentage of sprouting of "Sabiá" and "Mororó" shoot cuttings and a virtual lack of rooting were observed. However, regardless of species, the cuttings taken in the dry period had a greater percentage of sprouting (Lins et al., 2006), indicating an adaptation of these plants, probably because of an increased amount of reserve.

Collection of biological material in Brazil is regulated by the normative instruction n. 154 from IBAMA, published in the “Diário Oficial da União” n. 42, March, 2nd, 2007. This normative, among other regulations, established the Authorization and Information System on Biodiversity (SISBIO). Thus, researchers interested in native legume collection, for example, should consult this system.

\section{Native cacti from Caatinga}

The main native cacti from Caatinga with forage importance are "Mandacaru" (Cereus jamacaru P. DC.), "Xiquexique"(Pilosocereus gounellei (F.A.C. Weber) Byles \& Rowle), "Facheiro" (Pilosocereus pachycladus Ritter) and "Palmatória"(Opuntia palmadora Britton \& Rose). Araújo (2002) reported that the predominance of these species ranges among sites. This author reported densities of 1.55 and 1.50 plants/ha for "Facheiro" and "Mandacaru", respectively in a survey in the Petrolina region, Pernambuco state. In the Cariri, Paraíba state, a region with cooler nights and rainfall period from March to August (period of less evaporation); there are places where the "Facheiro" density can reach 400 plants/ha.

Table 4 - Dry matter yield of shrub-tree native plants or naturalized from Caatinga

\begin{tabular}{|c|c|c|c|c|}
\hline Trait & “Maniçoba” & "Flor-de-seda" & "Camaratuba” & Thorny “jurema-preta" \\
\hline DM yield $\left(\mathrm{kg}^{-1} \mathrm{ha}^{-1}\right)$ & 626.27 & 699.72 & 1832.88 & 2067 to 6467 \\
\hline Cutting height $(\mathrm{cm})$ & 20 & 40 & 40 & Leaves and branches up to $10 \mathrm{~mm}$ \\
\hline Spacing (m) & $1.0 \times 1.5$ & $1.0 \times 1.5$ & - & $1 \mathrm{~m} \times 1 \mathrm{~m}$ \\
\hline Age (days) & 240 & 60 & 365 & 365 \\
\hline Source & Beltrão et al. (2008) & Andrade et al. (2008) & Silva (1992) & Bakke et al. (2007) \\
\hline
\end{tabular}

Table 5 - “Sabiá” characteristics, in the municipality of Itambé, Pernambuco state

\begin{tabular}{|c|c|c|c|c|c|c|}
\hline Evaluation period & t height $(\mathrm{cm})$ & $\begin{array}{l}\text { Number of } \\
\text { sprouting }\end{array}$ & $\begin{array}{l}\text { Branch } \\
\text { length }(\mathrm{cm})\end{array}$ & $\begin{array}{l}\text { Branch } \\
\text { thickness }(\mathrm{mm})\end{array}$ & $\begin{array}{c}\text { Number of } \\
\text { thorny plants } / \mathrm{cm}^{2}\end{array}$ & $\begin{array}{c}\text { Grazed forage } \\
\left(\mathrm{kg}^{-1} \mathrm{DM} \mathrm{ha}^{-1} / 60 \text { days }\right)^{*}\end{array}$ \\
\hline April, June and August/06 & $165.4 \mathrm{~b}$ & $23.4 \mathrm{a}$ & $156.5 b$ & $7.6 \mathrm{~b}$ & $3.0 \mathrm{a}$ & $158.2 \mathrm{a}$ \\
\hline $\begin{array}{l}\text { September/05, November/05 } \\
\text { and February/06 }\end{array}$ & $205.7 \mathrm{a}$ & $24.5 \mathrm{a}$ & $199.7 \mathrm{a}$ & $10.2 \mathrm{a}$ & $3.3 \mathrm{a}$ & $146.9 \mathrm{a}$ \\
\hline
\end{tabular}

Means followed by the same letter within a column do not differ $(\mathrm{P}>0.05)$ by $\mathrm{F}$ test.

* Leaves and branches up to $5 \mathrm{~mm}$ of diameter and up to $2 \mathrm{~m}$ of height from the ground level.

Source: adapted from Caldas et al. (2010). 
Table 6 - "Xiquexique” and "Mandacaru” yield cultivated in the municipality of Cruzeta - RN

\begin{tabular}{|c|c|c|}
\hline Spacing (m) & Green matter & Dry matter \\
\hline & \multicolumn{2}{|c|}{ “Xiquexique” ( $\mathrm{kg}^{-1} \mathrm{ha}^{-1} 6.5$ years- $\left.{ }^{1}\right)$} \\
\hline $1.0 \times 1.0$ & 5,915 & 1,120 \\
\hline $1.5 \times 1.0$ & 5,254 & 1,008 \\
\hline $2.5 \times 1.0$ & 3,660 & 765 \\
\hline \multirow[t]{2}{*}{$2.5 \times 2.0$} & 1,980 & 424 \\
\hline & \multicolumn{2}{|c|}{ “Mandacaru” (kg-1 ha-110 years- $\left.{ }^{1}\right)$} \\
\hline $2.0 \times 1.5$ & 56,951 & 13,040 \\
\hline $3.0 \times 1.5$ & 45,090 & 9,361 \\
\hline $3.0 \times 2.0$ & 34,576 & 8,493 \\
\hline $3.0 \times 3.0$ & 28,918 & 6,717 \\
\hline
\end{tabular}

Source: adapted from Silva et al. (2007).

Although native cacti are important forage reserves for the Brazilian semiarid, they have low productivity, when compared, for example, to the forage cactus (Opuntia and Nopalea), a native cactus from Mexico. However, data of forage cactus yield cultivated under optimal conditions of environment and management shows that these conditions are determinant for forage yield.

\section{Nitrogen fixation in native plants}

The "Centro Nordestino de Informações Sobre Plantas" (CNIP) in 2002 listed 1,041 species found in the caatinga, $40 \%$ of which are from Leguminoseae family (Teixeira et al., 2006). Most species from this family have the $\mathrm{N}_{2}$-air fixation ability, therefore, the importance of these plants to maintain soil fertility in this region, as well as the large amount of crude protein concentration in the forage, has to be considered. However, not all legumes fix $\mathrm{N}_{2}$ and among the fixing ones, the proportion of fixed $\mathrm{N}_{2}$ changes widely (Boddey et al., 2000).

Quantitative estimates of $\mathrm{N}_{2}$ biological fixation and nodulation capacity of most species of Caatinga are scarce in literature or unknown. Freitas et al. (2010) estimated the biological fixation potential of some shrub-arboreous plants of the caatinga using the $15 \mathrm{~N}$ natural abundance technique. These authors identified species with potential to fix large amounts of $\mathrm{N}_{2}$, and the species that stood out were Mimosa tenuiflora (Willd.) Poir, M. arenosa (Willd.) Poir, and Piptadenia stipulacea (Benth.) Ducke. The biological fixation contribution was up to $68 \%$ of plant $N$, however, the annual $\mathrm{N}$ amount added from leaf biomass was low and ranged from 2.5 to $11.2 \mathrm{~kg} \mathrm{~N} \mathrm{ha}^{-1}$ year $^{-1}$, due to the low proportion of fixing plants in the botanical composition. At situations of native vegetation regeneration, when succession is marked by fixing species, the biological fixation can reach $130 \mathrm{~kg} \mathrm{~N}^{-1}$ year $^{-1}$.

\section{Selectivity of animals browsing on Caatinga areas}

The selection of entire plant or part of it by the animal indicates the potential of the forage species. Several native plants of caatinga are thorny, and this affects grazing habit and selection by the animals. In addition, thorns turn cutting management more difficult. Preference is not only determined by the animal but also by forage availability and botanical composition of the pasture (Peter, 1992).

Generally, the species found in the diet of the animals does not match with the percentage of species found in the botanical composition of the pasture. Thus, the chemical characteristics from the diet selected by the animals are mostly different from the characteristics of the pasture (Table 7).

Moreira et al. (2006) and Ydoyaga-Santana et al. (2010a) observed high number of species, from "Orelha-de-onça" to "Mororó", in the cattle diet. The percentage of grass in the diet decreased as the rainy season advanced (Table 8), and the inverse occurred with "Mororó", evidencing the importance of this legume in the feeding of animals grazing in the caatinga. It is important to notice that these authors performed the researches in the rainy season, thus some species that would probably be present in the diet during the dry season (when the leaves fall down) could not be observed. Also, there is a lack of efficient methodologies to evaluate the diet of animals grazing such heterogeneous pasture as caatinga.

Most woody plants present in the animal diet are selected in the caatinga litter, once the access to the forage

Table 7 - Chemical composition of the diet from sheep grazing thinned caatinga, in the municipality of Serra Talhada, Pernambuco state

\begin{tabular}{lcrrrr}
\hline \multirow{2}{*}{ Variable } & & \multicolumn{4}{c}{ Month } \\
\cline { 3 - 6 } & & March & April & May & June \\
\hline DM & $\%$ & 14.37 & 16.35 & 16.34 & 17.91 \\
MM & $\%$ DM & 13.17 & 16.00 & 12.36 & 11.95 \\
CP & $\%$ DM & 11.13 & 11.14 & 12.01 & 10.45 \\
EE & $\%$ DM & 2.26 & 1.92 & 1.94 & 2.34 \\
NDF & $\%$ DM & 64.95 & 64.62 & 63.47 & 64.78 \\
ADF & $\%$ DM & 49.65 & 52.98 & 52.64 & 51.34 \\
Lig & $\%$ DM & 14.63 & 16.15 & 16.35 & 16.00 \\
IPND & $\%$ CP & 72.87 & 72.98 & 66.44 & 72.06 \\
IPNA & $\%$ CP & 47.71 & 47.22 & 51.62 & 51.58 \\
IVDOM & $\%$ & 50.59 & 46.45 & 38.10 & 36.21 \\
CHOT & $\%$ DM & 73.44 & 72.81 & 73.69 & 75.26 \\
NFC & $\%$ DM & 16.60 & 16.32 & 18.20 & 18.01 \\
TDN & $\%$ & 38.54 & 35.67 & 36.65 & 38.10 \\
\hline
\end{tabular}

Source: Moreira et al. (2006).

$\mathrm{DM}=$ dry matter; $\mathrm{MM}=$ mineral matter; $\mathrm{CP}$ = crude protein; $\mathrm{EE}$ = ether extract; $\mathrm{NDF}=$ neutral detergent fiber; $\mathrm{ADF}=$ acid detergent fiber; Lig = lignin; IPND = insoluble protein neutral detergent; IPAD = insoluble protein acid detergent; IVDOM = in vitro digestibility of organic matter; CHOT = total carbohydrates; NFC = nonfiber carbohydrates; TDN = total digestible nutrients. 
Table 8 - Percentage of species in the cattle diet according to the evaluation period, in the municipality of Serra Talhada, Pernambuco state

\begin{tabular}{|c|c|c|c|c|}
\hline \multirow[t]{3}{*}{ Common name } & \multirow[t]{3}{*}{ Scientific name } & \multicolumn{3}{|c|}{ Evaluation period } \\
\hline & & May & June & July \\
\hline & & & $(\%)$ & \\
\hline Anil-de-bode & Tephrosia cinerea (L.)Pers. & - & - & 1.0 \\
\hline Aroeira & Myracrodruon urundeuva Fr. All. & - & - & 4.4 \\
\hline Engana-bobo & Diodia teres Walt. & 4.6 & 5.3 & 1.1 \\
\hline Grass & Not identified & 55.0 & 47.1 & 41.8 \\
\hline Juazeiro & Ziziphus joazeiro Mart. & 3.7 & 8.0 & 6.7 \\
\hline Jurema-preta & Mimosa SP & 2.3 & - & 6.5 \\
\hline Malva-branca & Pavonia cancelata Cav. & 1.7 & 3.6 & 5.3 \\
\hline Marmeleiro & Croton sonderianus Muell. Arg. & - & - & 0.8 \\
\hline Moleque-duro & Cordia leucocephala Moric & - & - & 3.9 \\
\hline Mororó & B. cheilantha (Bong.) Steud. & 14.2 & 18.0 & 19.7 \\
\hline Not identified & - & 0.8 & 2.0 & 2.0 \\
\hline Umbuzeiro & Spondias tuberosa Arr. Cam. & 1.7 & - & - \\
\hline
\end{tabular}

- not observed in the diet. Source: Ydoyaga-Santana et al. (2010a).

component of these plants is difficulted by their height. There is a seasonal fluctuation of forage availability in the different stratum of caatinga that changes the selectivity pattern of the animals. Araújo Filho et al. (1997) verified that, at the beginning of rainy season and at the end of dry season, most forage available for goats and sheep is composed by caatinga litter. As the rainy season advances, the herbage component tend to be the most important, however, when the dry season begins, the percentage of this component decreases in the available forage. The tree component has small percentage in the available forage compared to the herbage component and the caatinga litter.

Santos et al. (2008) observed that samples collected from two cannulas revealed 39 species with an average of 20 species occurring in each monthly sampling. Poaceas, Herisanthia tiubae K.Schum. Bri and Sida galheirensis Ulbr were the most important botanical components of the diet selected by the animals, at every sample collection time. Ziziphus joazeiro Mart. and Capparis flexuosa L. L. were also present in the samples almost all year.

It should be emphasized that, besides the sample collection time and forage availability, the access of the animals is another factor that affects the diet composition (plant fractions). In the thinned caatinga, Pimentel et al. (1992) observed high proportion of leaves compared to stem in the diet of sheep grazing native pastures. Santos et al. (2008) also detected that almost all year the fraction of leaves had the highest percentage in the sheep diet, independently of the sampling month (Table 9) and noticed a significant participation of fruits in the diet composition.

Therefore, animals are efficient in diet selection, not only by selecting specific plants but also by selecting the same fraction of the plants according to the season of the year. However, as grazing phytomass reduces with the advance of the dry season, the selective behavior of the animals gets compromised.

Table 9 - Percentage plant fraction in the diet of sheep grazing caatinga, according to the collection month, in the municipality of Sertânia, Pernambuco state

\begin{tabular}{|c|c|c|c|c|c|}
\hline \multirow[t]{2}{*}{ Month } & \multicolumn{5}{|c|}{ Plant fraction (\%) } \\
\hline & Leaf & Stem & Fruit & Seed & Flower \\
\hline September & $62.41 \pm 23.43 a$ & $11.53 \pm 6.15 a b$ & $10.97 \pm 6.97 \mathrm{ab}$ & $7.94 \pm 9.39 \mathrm{ab}$ & $0.00 \mathrm{~b}$ \\
\hline January & $55.59 \pm 18.26 a$ & $14.85 \pm 9.13 a$ & $14.53 \pm 12.39 \mathrm{ab}$ & $14.98 \pm 13.83 a$ & $0.00 \mathrm{~b}$ \\
\hline March & $73.88 \pm 19.61 \mathrm{a}$ & $6.81 \pm 6.61 \mathrm{ab}$ & $17.13 \pm 21.53 \mathrm{ab}$ & $2.16 \pm 2.15 b$ & $0.00 \mathrm{~b}$ \\
\hline May & $59.41 \pm 18.95 a$ & $10.74 \pm 6.10 \mathrm{ab}$ & $20.41 \pm 21.68 a$ & $3.36 \pm 5.05 b$ & $6.06 \pm 11.08 \mathrm{ab}$ \\
\hline July & $58.00 \pm 17.23 a$ & $9.25 \pm 4.90 \mathrm{ab}$ & $15.87 \pm 13.95 a b$ & $1.53 \pm 1.78 b$ & $15.34 \pm 22.16 \mathrm{a}$ \\
\hline
\end{tabular}

Means followed by the same letter within a column do not differ $(\mathrm{P}>0.05)$ by Tukey test.

Source: adapted from Santos et al. (2008). 
Nutritive value of native plants from caatinga

Forage quality is determined by its nutritive value, which is determined by the chemical composition, intake, and digestibility. Crude protein (CP) content has been considered an important parameter for the evaluation of the nutritive value of forage. Other factors such as secondary components and digestibility of the forage cell wall that can seriously restrain intake are also important.

Most studies about forage from caatinga found in literature concerns the chemical composition of these species. The results found by Moreira et al. (2006) corroborate with the fact that many species has high CP content and low digestibility (Table 10).

Even if crude protein contents are high and meet the animal requirements for protein, during a short period (rainy season), a deep evaluation of the available nitrogen for ruminal microorganisms and the animal is necessary, once it may be linked to the cell wall (NIDA) and, consequently, pass through the gastrointestinal tract intact without being absorbed.

The correct evaluation of chemical composition and of in vitro digestibility is the first step for the nutritional evaluation of these forages, but much more studies are necessary to evaluate the carbohydrates and protein fractions, intake and animal performance. It is well known in literature that information about intake evaluation and total digestibility of animals fed exclusively these forages are scarce, compromising the real evaluation of the nutritive value of in natura or preserved plants. On the other side, these forages are usually evaluated when used as diet ingredient for animals kept in feedlot or grazing directly in the caatinga (where the animal has a broad group of botanical species available). However, in these cases, the specific knowledge about the nutritive potential of determined forage may be misunderstood due to an associative effect.

Santos et al. (2009) observed that the diet of sheep grazing in caatinga determined low results concerning in situ degradability of dry matter, neutral detergent fiber and crude protein (Table 11).

\section{Forage conservation of native plants from Caatinga}

Forage conservation techniques can be an alternative for strategic use of native plants, whereas most plants are deciduous. Haymaking and ensiling processes can contribute by decreasing anti-nutritional components, as for example the "Maniçoba" (Manihot ssp). However, collecting material in the caatinga area is difficult, and then additional cost must be aggregated to the conserved forage.

Manihot plants have substances that when hydrolyzed originate hydrocyanic acid, a toxic product that can cause death of the animal when ingested in excessive amount. However the hydrocyanic acid is easily volatilized when the plant is triturated and exposed to the sun, and its concentration decreases during the fermentation in the ensiling process.

The chemical composition of hay forages of Caatinga is directly associated to the phenologic stage of the harvested plant (Table 12). Most researches in literature describe shrub-tree species but information about herbage stratum, and grasses, are few. Morais et al. (2009) pointed that, part of hay protein of 'capim-de-raiz' is not available, because it is linked to the cell wall thus, the real intake of protein is low.

Considering the high number of woody species in the caatinga, the presence of tannin is important in the

Table 10 - Chemical composition of some native species found in the diet of cattle, in the municipality of Sertânia, Pernambuco state

\begin{tabular}{|c|c|c|c|c|c|c|c|c|}
\hline \multirow[b]{2}{*}{ Specie } & \multirow[b]{2}{*}{ DM (\%) } & \multicolumn{5}{|c|}{$\% \mathrm{DM}$} & \multirow[b]{2}{*}{ IVDDM (\%) } & \multirow[b]{2}{*}{ IVDOM (\%) } \\
\hline & & $\mathrm{CP}$ & NDF & $\mathrm{ADF}$ & $\mathrm{MM}$ & $\mathrm{EE}$ & & \\
\hline Angico & 68.41 & 14.58 & 35.35 & 28.16 & 6.51 & 1.73 & 24.35 & 26.05 \\
\hline Aroeira & 55.31 & 11.44 & 35.7 & 29.97 & 5.56 & 2.55 & 25.62 & 27.13 \\
\hline Capim-buffel & 45.64 & 7.76 & 68.17 & 53.16 & 7.97 & 1.37 & 22.07 & 23.98 \\
\hline Capim-urochloa & 41.27 & 5.02 & 72.80 & 51.15 & 9.71 & 0.71 & 28.15 & 31.18 \\
\hline Catingueira & 58.21 & 13.3 & 38.66 & 27.8 & 8.17 & 2.89 & 35.63 & 38.80 \\
\hline Engana-bobo & 41.77 & 7.61 & 74.15 & 57.21 & 9.03 & 1.06 & 35.67 & 39.21 \\
\hline Jurema-preta & 47.68 & 16.88 & 40.64 & 36.92 & 4.55 & 2.96 & 11.19 & 11.72 \\
\hline Juazeiro & 47.08 & 13.23 & 54.76 & 35.03 & 10.22 & 0.71 & 32.02 & 35.66 \\
\hline Malva-branca & 52.81 & 9.21 & 70.16 & 37.81 & 6.80 & 1.62 & 41.92 & 44.98 \\
\hline Malva-rasteira & 54.17 & 13.48 & 58.97 & 35.74 & 8.40 & 2.57 & 41.43 & 45.23 \\
\hline Marmeleiro & 42.82 & 13.10 & 44.01 & 38.41 & 7.49 & 1.74 & 10.12 & 10.94 \\
\hline Moleque-duro & 53.76 & 11.66 & 51.04 & 45.03 & 17.21 & 1.45 & 30.16 & 36.43 \\
\hline Mororó & 46.83 & 12.85 & 49.06 & 40.53 & 6.43 & 1.84 & 30.51 & 32.61 \\
\hline Orelha-de-onça & 44.70 & 11.74 & 62.25 & 47.57 & 10.84 & 0.74 & 36.75 & 41.22 \\
\hline Pereiro & 47.14 & 11.36 & 39.46 & 34.19 & 11.48 & 2.86 & 31.02 & 35.04 \\
\hline
\end{tabular}

Source: Moreira et al. (2006). 
Table 11 - Potential degradability (PD) of the diet nutrients from sheep grazing the caatinga, in the municipality of Sertânia, Pernambuco state

\begin{tabular}{|c|c|c|c|c|c|}
\hline \multirow[t]{2}{*}{ Variable (\%) } & \multicolumn{5}{|c|}{ Month } \\
\hline & November & January & March & May & July \\
\hline PDDM & $48.65 \pm 6.69 c$ & $52.41 \pm 6.39 c$ & $64.63 \pm 7.06 \mathrm{a}$ & $63.76 \pm 8.66 \mathrm{ab}$ & $55.87 \pm 9.98 b c$ \\
\hline PDNDF & $36.43 \pm 7.24 c$ & $39.28 \pm 5.10 \mathrm{bc}$ & $51.44 \pm 7.57 a$ & $54.34 \pm 9.51 \mathrm{a}$ & $47.83 \pm 8.67 \mathrm{ab}$ \\
\hline PDCP & $62.13 \pm 8.21 b$ & $75.74 \pm 6.47 a$ & $77.24 \pm 6.56 a$ & $71.27 \pm 9.72 \mathrm{ab}$ & $63.67 \pm 11.27 b$ \\
\hline
\end{tabular}

Means followed by the same letter within a column do not differ $(\mathrm{P}>0.05)$ by Tukey test.

Source: adapted from Santos et al. (2009).

Table 12 - Chemical composition of hays from native forages of Caatinga

\begin{tabular}{|c|c|c|c|c|c|}
\hline Variable & 'Capim-de-raiz' & 'Mororó’ & 'Sabiá' & 'Catingueira' & ‘Juazeiro’ \\
\hline DM (\%) & 90.66 & 87.50 & 88.15 & 85.39 & 92.30 \\
\hline OM (\%) & 91.41 & 93.08 & 95.00 & 95.42 & - \\
\hline $\mathrm{MM}(\%)$ & 8.59 & 6.93 & 5.12 & 4.58 & 11.8 \\
\hline СР (\%) & 7.16 & 15.50 & 18.50 & 12.31 & 15.2 \\
\hline NDF (\%) & 65.34 & 60.50 & 65.50 & 47.11 & 66.7 \\
\hline ADF (\%) & 37.9 & 52.50 & 59.50 & 28.48 & 41.9 \\
\hline TC $(\%)$ & 82.25 & 76.57 & 75.33 & 81.22 & - \\
\hline NFC (\%) & 16.91 & 16.07 & 9.83 & 34.11 & - \\
\hline Cellulose (\%) & - & - & - & 38.19 & 27.6 \\
\hline $\operatorname{ADIN}^{2}(\%)$ & 13.42 & - & - & - & - \\
\hline ADIN (\%CP) & - & - & 6.2 & - & - \\
\hline Tannin & - & 3.26 & 3.42 & - & - \\
\hline Source & Morais et al. (2009) & Goyanna (2009) & Goyanna (2009) & Mendonça Jr. et al. (2008) & Barros et. al. (1991) \\
\hline
\end{tabular}

${ }^{1}$ Dry matter basis; ${ }^{2} \%$ total N.

evaluation of these forages. Pereira Filho et al. (2005) observed that the increasing tannin concentration in the “jurema-preta” (Mimosa tenuiflora Wild) hay negatively affected the dry matter degradability and more intensively the crude protein degradation in sheep.

As described earlier, there are few papers in literature about nutrient intake and digestibility along the gastrointestinal tract of animals fed only Caatinga forages. It is known that nutrient digestibility is affected by factors inherent to feed, animal species, animal age, intake level, and feed processing. Recent researches (Tables 13 and 14) demonstrated that animals have been presenting mostly adequate intake and nutrient utilization for maintenance when fed exclusively hay of native Caatinga forages or as complementary ingredients in the diet under more intensive production systems.

The use of cactus in the animal feeding under semiarid conditions is an alternative (Table 15). Cactus has high palatability but the thorns may difficult its intake. The removal of these thorns is usually done by burning the cactus, but this practice affects its forage composition (Pinto et al., 2007). Although cactus showed adequate chemical composition, factors like low density and phytomass of plants, the need of thorn elimination and transportation to troughs turns the use of these species more expensive, mainly when they are collected inside the
Table 13 - Average values of nutrient intake (I) of native forage hay from Caatinga

\begin{tabular}{lccc}
\hline Variable & “Capim-de-raiz” & “Mororó” & "Sabiá” \\
\hline DMI (g/day) & $390.53 \pm 52.42$ & 592.06 & 726.60 \\
DMI (\% BW) & $1.39 \pm 0.19$ & 3.17 & 4.10 \\
OMI (g/d) & $359.75 \pm 34.88$ & 563.56 & 714.76 \\
MMI (g/d) & $31.04 \pm 3.93$ & 35.21 & 25.91 \\
CPI (g/d) & $20.20 \pm 7.22$ & $90.84 \mathrm{~b}$ & $141.33^{\mathrm{a}}$ \\
TCI (g/d) & $381.65 \pm 20.93$ & 460.45 & 552.32 \\
NDFI (g/d) & $270.04 \pm 19.22$ & $368.26 \mathrm{~b}$ & $498.31^{\mathrm{a}}$ \\
NDFI (\% BW) & $0.96 \pm 0.06$ & $1.97 \mathrm{~b}$ & $2.80^{\mathrm{a}}$ \\
NDFI (g/MW) & $22.12 \pm 1.47$ & $40.93 \mathrm{~b}$ & $57.54^{\mathrm{a}}$ \\
NFCI (g/d) & $78.46 \pm 4.39$ & $92.19 \mathrm{a}$ & $54.01 \mathrm{~b}$ \\
TDNI (g/d) & $293.98 \pm 23.79$ & 405.11 & 518.52 \\
Animal specie & Sheep & Goat & Goat \\
Source & Morais et al. & Goyanna & Goyanna \\
& $(2009)$ & $(2009)$ & $(2009)$ \\
\hline
\end{tabular}

Table 14 - Average coefficients of digestibility (CD) of hay nutrients of native forage

\begin{tabular}{lccc}
\hline Variable & “Capim-de-raiz” & “Mororó” & "Sabiá” \\
\hline CDDM & 52.80 & 70.10 & 70.58 \\
CDOM & 53.12 & 71.82 & 73.25 \\
CDCP & 70.55 & 66.50 & 67.60 \\
CDNDF & 40.39 & 70.30 & 69.70 \\
CDTC & 55.74 & 72.28 & 73.10 \\
CDNFC & 56.32 & 73.73 & 53.79 \\
TDN & 56.48 & 67.77 & 70.81 \\
Animal specie & Sheep & Goat & Goat \\
Source & Monteiro et al. & Goyanna & Goyanna \\
& $(2009)$ & $(2009)$ & $(2009)$ \\
\hline
\end{tabular}

R. Bras. Zootec., v.39, p.204-215, 2010 (supl. especial) 
Table 15 - Chemical composition of some native cacti of caatinga

\begin{tabular}{|c|c|c|c|c|c|c|c|c|c|}
\hline \multirow[b]{2}{*}{ Specie } & \multirow[b]{2}{*}{ DM (\%) } & \multicolumn{6}{|c|}{$\% \mathrm{DM}$} & \multirow[b]{2}{*}{ IVDDM (\%) } & \multirow[b]{2}{*}{ Source } \\
\hline & & CP & NDF & TC & NFC & $\mathrm{MM}$ & $\mathrm{EE}$ & & \\
\hline Mandacaru & 16.4 & 8.2 & - & - & & 10.5 & - & - & Araújo (2002) \\
\hline Xiquexique & 13.6 & 4.9 & - & - & & 13.7 & - & - & Araújo (2002) \\
\hline Facheiro & 8.2 & 9.2 & - & - & - & - & - & - & $\begin{array}{l}\text { Adapted from } \\
\text { Germano et al. (1991) }\end{array}$ \\
\hline Xiquexique & 16.4 & 6.1 & 39.9 & 76.4 & 36.0 & & 1.1 & & Silva et al. (2005) \\
\hline
\end{tabular}

Caatinga. Therefore, these plants will only be used to feed animals during severe droughts (Araújo, 2002).

\section{Animal performance}

Dry matter ingestion is responsible for 60 to $90 \%$ on changes at animal performance, while 10 to $40 \%$ can be attributed to forage digestibility (Mertens, 1994).

The amount of forage available, which is highly affected by the rainfall distribution, is an important factor for the performance of animals browsing on caatinga that is usually low, mainly in the dry season. Caatinga management is an alternative to change the amount and quality of forage available for the animals and, consequently increase animal performance.

Ydoyaga-Santana et al. (2010b), studying Guzera and Gyr x Holstein heifers browsing managed caatinga in the rainy season found average daily weight of $412 \mathrm{~g}$ (Table 16). The authors affirmed that this performance is probably due to the stocking rate of $6 \mathrm{ha}^{-1} \mathrm{AU}^{-1}$, that allowed the animals a higher selectivity, and also to the high prevalence of Buffel and "Corrente" grasses in the pasture.

Leite et al. (2002) studying the nutritional balance of sheep grazing native pastures (caatinga) at 4-breeding levels observed that, although the dietary energetic balance was favored by fertilization and enrichment with "Gramão” grass (Cynodon dactylon) of the thinned caatinga, the energy deficit were higher and more frequent than the protein ones, for all caatinga breeding levels, mainly during the pregnancy and lactation periods of sheep. Araujo Filho et al. (2002) observed that the best animal production results in caatinga were obtained in thinned caatinga with cattle grazing alone and along with goats and sheep (Table 17). Grasses are the most important component in the cattle diet, therefore this fact is probably associated to a higher predominance of grasses and a high availability of phytomass for grazing in thinned plots.

Even with the caatinga management that can increase forage availability, protein content, digestibility and organic matter intake, this practice was not enough to meet the energy and protein requirements of the animals during the dry season. Thus, to maintain acceptable levels of animal production in this period it is necessary to supply feed in the trough. However, the feed choice will depend on the technological level of the farm, as well as the economic and physical resources available.

Most results reported in literature that evaluate the performance of animals fed hay of native forages deals with the inclusion of different levels of these forages in the diet, usually replacing ingredients that are more expensive. Castro (2004) evaluated the inclusion of 20-80\% of "Maniçoba" hay in the diet of growing sheep and observed that daily weight gain decreased as the percentage of hay increased (Table 18), thus, a decrease of $1.43 \mathrm{~g} /$ day per unit of hay added to the diet, could be estimated from these results. Silva et al. (2005) included 0, 12.5, 25, 37.5 and 50\% of 'Xiquexique' in replacement with sorghum silage in the diets of lactating Brown Swiss cows and reported that nutrient intake was enough to meet the animal requirements for milk yield, with no effect on the milk chemical composition.

Table 16 - Chemical composition, intake and performance of heifers under native pasture, in the municipality of Serra Talhada, Pernambuco state

\begin{tabular}{|c|c|c|c|c|c|c|c|c|}
\hline \multirow[t]{2}{*}{ Forage chemical composition } & $\mathrm{DM}$ & $\mathrm{CP}$ & NDF & $\mathrm{ADF}$ & $\mathrm{EE}$ & $\mathrm{MM}$ & ISDMD & TDN \\
\hline & 55.7 & 12.6 & 57.0 & 45.0 & 1.7 & 8.8 & 31.8 & 56.0 \\
\hline DM intake $\left(\mathrm{kg}^{-1}\right.$ animal $^{-1}$ day $\left.^{-1}\right)$ & \multicolumn{8}{|c|}{4.83} \\
\hline DM intake (\%MW) & \multicolumn{8}{|c|}{2.1} \\
\hline CP intake $\left(\mathrm{g}^{-1}\right.$ head $^{-1}$ day $\left.^{-1}\right)$ & \multicolumn{8}{|c|}{608.58} \\
\hline TDN intake $\left(\mathrm{g}^{-1}\right.$ head $^{-1}$ day $\left.^{-1}\right)$ & \multicolumn{8}{|c|}{2704.80} \\
\hline Daily gain $\left(\mathrm{g}^{-1} \mathrm{cow}^{-1} \mathrm{day}^{-1}\right)$ & \multicolumn{8}{|c|}{412} \\
\hline
\end{tabular}

Source: adapted from Ydoyaga-Santana et al. (2010b). 
Table 17 - Body weight production $\left(\mathrm{kg}^{-1} \mathrm{ha}^{-1} \mathrm{year}^{-1}\right)$ from different animal arrangement in the managed caatinga

\begin{tabular}{lccc}
\hline Arrangement & Control & Cutting & Thinning \\
\hline Bovine & 5.6 & 22.3 & 57.8 \\
Goat & 11.9 & 41.3 & 33.8 \\
Sheep & 9.7 & 19.5 & 32.5 \\
Bovine + Goat & 7.4 & 39.0 & 43.9 \\
Bovine + Sheep & 10.4 & 24.8 & 47.5 \\
Goat + Sheep & 12.1 & 27.2 & 34.4 \\
Bovine + Goat + Sheep & 13.8 & 28.4 & 51.9 \\
\hline
\end{tabular}

Source: Aráujo Filho et al. (2002).
In general, animal performance is low under conditions of native caatinga (Lira et al., 1990), especially in the dry season. The caatinga management may be an alternative to improve the quantity and quality of forage and consequently the animal performance. Studies that report details of the qualitative and quantitative changes of native forages of Caatinga, considering the physical and climate effects, are essential for the management of feeding supplementation, aiming at the sustainability of livestock production in caatinga area.

Table 18 - Daily weight gain (DWG), feed:gain ratio (F/G), feeding efficiency (FE) and final weight of sheep fed “maniçoba” hay in the diet

\begin{tabular}{|c|c|c|c|c|c|c|c|}
\hline \multirow[b]{2}{*}{ Variable } & \multicolumn{4}{|c|}{ \% "maniçoba" hay in the diet } & \multirow[b]{2}{*}{$\mathrm{CV}(\%)$} & \multirow[b]{2}{*}{$\mathrm{RE}$} & \multirow[b]{2}{*}{$\mathrm{R}^{2}$} \\
\hline & 20 & 40 & 60 & 80 & & & \\
\hline DWG $\left(\mathrm{g}^{-1}\right.$ day $\left.^{-1}\right)$ & 290.84 & 293.62 & 253.35 & 208.48 & 14.7 & $\mathrm{Y}=333.42-1.4368 * * \mathrm{X}$ & 0.86 \\
\hline $\mathrm{F} / \mathrm{G}$ & 4.01 & 4.38 & 4.92 & 5.73 & 11.6 & $\mathrm{Y}=3.332+0.0286 * * \mathrm{X}$ & 0.97 \\
\hline $\mathrm{FE}$ & 0.25 & 0.23 & 0.21 & 0.17 & 12.2 & $\mathrm{Y}=0.28-0.0013^{* *} \mathrm{X}$ & 0.98 \\
\hline FW (kg) & 30.67 & 32.11 & 30.18 & 28.02 & 7.0 & $\mathrm{Y}=34.271-0.0721^{* *} \mathrm{X}$ & 0.86 \\
\hline
\end{tabular}

Source: adapted from Castro (2004).

\section{Conclusions}

There is little information about the quantitative aspects of caatinga plants, mainly for the herbage stratum. Evaluation methodologies are intricated, without uniformity and not fully detailed, therefore, the comparison of results concerning forage potential of some plants of caatinga gets compromised. Index species should be identified according to the caatinga type. Grasses, 'Orelha-de-onça', and 'Mororó' components are very important in the diet selected by the animals and should be preserved mainly due to the animal trampling. Also, these plants could be used in a domestication program. Promising species that perform biological fixation of $\mathrm{N}$-air were identified; however more researches are necessary to increase the diversity of their utilization in order to improve social, economical and environmental situations. A more detailed research on $\mathrm{N}$ availability for ruminants from caatinga plant species is necessary. Previous researches have indicated high proportion of ADIN in these species. More studies that evaluate the qualitative and quantitative changes of native forages of Caatinga are important for feeding supplementation management, aiming the sustainability of animal production in the Caatinga areas.

\section{Referências}

ALBUQUERQUE, S.G.; SOARES, J.G.G.; GUIMARÃES FILHO, C. Effect of grazing by steers and a long drought on a caatinga ligneous stratum in semi-arid northeast, Brazil. Caatinga, v.21, n.4, p.17-28, 2008.

ALENCAR, F.H.H. Potencial forrageiro da espécie sabiá (Mimosa Caesalpiniifolia benth.) e sua resistência a cupins subterrâneos. 61f. 2006. Dissertação (Mestrado em Zootecnia - Sistemas Agrossilvipastoris no Semiárido) Universidade Federal de Campina Grande, Campina Grande.

ANDRADE-LIMA, D. The caatinga dominium. Revista Brasileira de Botânica, v.4, p.149-153, 1981.

ANDRADE, M.V.M.; ANDRADE, A.P.; SILVA, D.S. et al. Levantamento florístico e estrutura fitossociológica do estrato herbáceo e subarbustivo em áreas de caatinga no Cariri Paraibano. Caatinga, v.22, n.1, p.229-237, 2009.

ANDRADE, M.V.M.; SILVA, D.S.; ANDRADE, A.P. et al. Produtividade e qualidade da flor-de-seda em diferentes densidades e sistemas de plantio. Revista Brasileira de Zootecnia, v.37, n.1, p.1-8, 2008.

ARAÚJO, G.G.L. Alternativas de alimentação para caprinos. In: SIMPÓSIO PARAIBANO DE ZOOTECNIA, 3., 2002, Areia. Anais... Areia: UFPB, 2002. (CD-ROM).

ARAÚJO FILHO, J.A. Aspectos zooecológicos e agropecuários do caprino e do ovino nas regiões semiáridas. Sobral: Embrapa Caprinos, 2006. 28p. (Documentos, 61).

ARAÚJO FILHO, J.A.; CRISPIM, S.M.A. Pastoreio combinado de bovinos, caprinos e ovinos em áreas de caatinga no Nordeste do Brasil. In: CONFERÊNCIA VIRTUAL GLOBAL SOBRE PRODUÇÃO ORGÂNICA DE BOVINOS DE CORTE, 1., 2002. Disponível em: <www.conferencia.uncnet.br/ pantanal/index.php?lin=pt.>. Acesso em: 3/2/2010. 
ARAÚJO FILHO, J.A.; GADELHA, A.G.; CRISPIM, S.M.A. et al. Pastoreio misto em caatinga manipulada no Sertão Cearense. Revista Cientifica de Produção Animal, v.4, n.1-2, p.921, 2002

ASSIS, W.P. Efeito da época de abertura da pastagem de capim buffel (Cenchrus ciliaris L.) no ressurgimento da leguminosa nativa orelha de onça (Macroptilium martii Benth). 113f. 1992. Dissertação (Mestrado em Produção Animal) - Universidade Federal Rural Pernambuco, Recife.

BARROS, N.N.; FREIRE, L.C.L.; LOPES, E.A. et al. Valor nutritivo do feno de juazeiro (Zizyphus joaz ) para caprinos e ovinos. Pesquisa Agropecuária Brasileira, v.26, n.8, p.1299-1394, 1991.

BAKKE, I.A.; BAKKE, O.A.; ANDRADE, A.P. et al. Forage yield and quality of a dense thorny and thornless "jurema-preta" stand. Pesquisa Agropecuária Brasileira, v.42, n.3, p.341347, 2007.

BELTRÃO, F.A.S.; PIMENTA FILHO, E.C.; PAES, R.A. et al. Comportamento da maniçoba (manihot pseudoglaziovii muell arg) sob diferentes espaçamentos e adubações. Caatinga, v.21, n.4, p.163-166, 2008.

BODDEY, R.M.; PEOPLES, M.B.; PALMER, B. et al. Use of the $15 \mathrm{~N}$ natural abundance technique to quantify biological nitrogen fixation by woody perennials. Nutrient Cycling in Agroecosystems, v.57, p.235-270, 2000.

BRASIL. Ministério da Integração Nacional/SDR. Relatório Final do Grupo de Trabalho Interministerial para Redelimitação do Semiárido Nordestino e do Polígono das Secas. Ministério da Integração Nacional, Brasília. 2005.

CALDAS, G.G.; SANTOS, M.V.F.; LIRA JR., M.A. et al. Caracterização morfológica e composição química de plantas de Mimosa caesalpiniifolia Benth submetidas à fertilização fosfatada, em diferentes épocas do ano. Archivos de Zootecnia, 2010. Prelo.

CASTRO, J.M.C. Inclusão do feno de maniçoba (Manihot glazioviiMuel Arg.) em dietas para ovinos Santa Inês. 95f. 2004. Tese (Doutorado em Zootecnia) - Universidade Federal da Paraiba, Areia.

INSTITUTO BRASILEIRO DE GEOGRAFIA E ESTATÍSTICA IBGE. Mapa de biomas do Brasil, primeira aproximação. Rio de Janeiro: 2004.

INSTITUTO BRASILEIRO DE GEOGRAFIA E ESTATÍSTICA IBGE. Contagem da população. Rio de Janeiro: 2007.

INSTITUTO BRASILEIRO DE GEOGRAFIA E ESTATÍSTICA IBGE. Censo Agropecuário 1995-1996. Rio de Janeiro: 1997.

FERNANDES, A.P.M.; FARIAS, I.; LIRA, M.A. et al. Efeito de diferentes períodos de diferimento sobre o pasto de capim-deraiz (Chloris orthonoton Doell). In: CONGRESSO BRASILEIRO DE FORRAGEIRAS E PASTAGENS NATIVAS, 1., 1983, Olinda. Anais... Olinda: IPA, 1983. s.n.p.

FREITAS, A.D.S.; SAMPAIO, E.V.S.B.; SANTOS, C.E.R.S. et al. Biological nitrogen fixation in tree legumes of the Brazilian semi-arid caatinga. Journal of Arid Environments, v.74, p.344-349, 2010.

GERMANO, R.H.; BARBOSA, H.P.; COSTA, R.G. et al. Avaliação da composição química e mineral de seis cactáceas do semiárido paraibano. In: REUNIÃO ANUAL DA SOCIEDADE BRASILEIRA DE ZOOTECNIA, 28., João Pessoa, 1991. Anais... João Pessoa: SBZ, 1991. p.3.

GUIMARÃES FILHO, C.; SOARES, J.G.G.; RICHÉ, G.R. Sistema caatinga-buffel-leucena para produção de bovinos no semiárido. Petrolina: Embrapa-CPATSA, 1995. 39p. (Circular Técnica, 34).

GOYANNA, G.J.F. Nível de oferta de alimento sobre o consumo e digestibilidade do feno de sabiá (Mimosa caesalpiniifolia Benth) e mororó (Bauhinia cheilantha (Bong) Steud), em caprinos. 40f. 2009. Dissertação (Mestrado em Zootecnia) - Universidade Federal Rural Pernambuco, Recife.
LEAL, I.R.S.; TABARELLI, M.; LACHER JR., T.E. Mudando o curso da conservação da biodiversidade na Caatinga do Nordeste do Brasil. Megadiversidade, v.1, n.1, p.139-146, 2005.

LEITE, E.R.; CÉSAR, M.F.; ARAÚJO FILHO, J.A. Efeitos do melhoramento da caatinga sobre os balanços protéico e energético na dieta de ovinos. Ciência Animal, v.12, n.1, p.67-73, 2002.

LIMA, G.F.C. Determinação da área disponível ao acesso animal em caatinga pastejada- Regiıo de Ouricuri-PE. 244f. 1984. Dissertação (Mestrado em Nutrição Animal) Universidade Federal Rural de Pernambuco.

LINS, M.M.; LIMA, A.F.; SANTOS, M.V.F. et al. Velocidade de brotação de estacas de Sabiá ( $M$. caesapiniaefolia ) e Mororó (B. cheilanta (Bong) Stend) em diferentes tipos de substratos e período de colheita. In: ZOOTEC 2006, Olinda. Anais... Recife: UFRPE, 2006.

LIRA, M.A.; FARIAS, I.; SANTOS, M.V.F. Alimentação de bovinos no Nordeste - Experimentação com forrageiras e pastagens. In: SIMPOSIO NORDESTINO DE ALIMENTACAO DE RUMinAnteS, 3., 1990, João Pessoa. Anais... João Pessoa: SNAR, 1990. p. 108-133

MENDONÇA JR., A.F.; BRAGA, A.P.; GALVÃO, R.J.D. Composição bromatológica, consumo e digestibilidade in vivo de dietas com diferentes níveis de feno de catingueira (Caesalpinea pyramidalis Tul), fornecidas para ovinos SRD. Revista de Biologia e Ciências da Terra, v.8, n.1, p.190-197, 2008.

MERTENS, D.R. Regulation of forage intake. In: FARHEY JR., G.C. (Ed.) Forage quality evaluation and utilization. Madson:American Society of Agronomy/Crop Science Society of American/Soil Science Society of American, 1994. p.450-493.

MONTEIRO, C.C.F.; GUIM, A.; SOUZA, E.J.O. et al..Composição química e digestibilidade de nutrientes do feno de capim-de-raiz (Chloris orthinoton doell) em ovinos. In: JORNADA DE ENSINO, PESQUISA E EXTENSÃO DA UFRPE, 9., 2009. Recife. Anais... Recife: UFRPE, 2009. (CD-ROM).

MOREIRA, J.N.; LIRA, M.A.; SANTOS, M.V.F. et al. Caracterização da vegetação de Caatinga e da dieta de novilhos no Sertão de Pernambuco. Pesquisa Agropecuária Brasileira, v.41, n.11, p. 1643-1651, 2006.

MOREIRA, J.L.; LIRA, M.A.; SANTOS, M.V.F. et al. Consumo e desempenho de vacas guzerá e girolando na caatinga do sertão pernambucano. Caatinga, v.20, n.3, p.13-21, 2007.

MORAIS, N.A.P.; GUIM, A.; SOUZA, E.J.O. et al. Composição química e Consumo de nutrientes do feno de capim de raiz (Chloris orthonoton Doell) em ovinos. In: JORNADA DE ENSINO, PESQUISA E EXTENSÃO DA UFRPE, 9., 2009. Recife. Anais... Recife: UFRPE, 2009. (CD-ROM).

PEREIRA FILHO, J.M.; VIEIRA, E.L.; KAMALAK, A. et al. Correlação entre o teor de tanino e a degradabilidade ruminal da matéria seca e proteína bruta do feno de jurema-preta (Mimosa tenuiflora Wild) tratada com hidróxido de sódio. Livestock Research for Rural Development. v.17, n.8, 2005. Available in: <http://www.lrrd.org/lrrd17/8/ pere17091.htm>

PETER, A.M.B. Composição botânica e química da dieta de bovinos, caprinos e ovinos em pastejo associativo na Caatinga nativa do Semiárido de Pernambuco. 1992. 86f. Dissertação (Mestrado em Nutrição Animal) Universidade Federal Rural de Pernambuco, Recife.

PIMENTEL, J.C.N.; ARAÚJO FILHO, J.A.; NASCIMENTO JR., D. et al. Composição química e DIVMO da dieta de ovinos em área de caatinga raleada no sertão Centro-Norte do Ceará. Revista Brasileira de Zootecnia, v.21, n.2, p.224-232, 1992.

PINTO, M.S.C.; ARAÚJO FILHO, J.M.; COSTA, T.G.P. et al. Bromatologic composition of the xique-xique (Cereus gounellei.) under two methods of removing thorns. In: INTERNATIONAL CONGRESS ON CACTUS PEAR AND COCHIENAL, 6., 2007, João Pessoa. Proceedings... João Pessoa: FAEPA/FAO/CACTUSNET, 2007. (CD-ROM). 
SÁ, I.B.; RICHÉ, G.R.; FOTIUS. G.A. As paisagens e o processo de degradação do semiárido nordestino. In: SILVA, J.M.C.; TABARELLI, M.; FONSECA, M.T. et al. (Eds.) Biodiversidade da Caatinga: áreas e ações prioritárias para a conservação. Brasília: Ministério do Meio Ambiente; Universidade Federal de Pernambuco, 2003. p.18-36.

SANTOS, G.R.A.; BATISTA, A.M.V.; GUIM, A. et al. Determinação da composição botânica da dieta de ovinos em pastejo na Caatinga. Revista Brasileira de Zootecnia, v.37, p.18761833, 2008.

SANTOS, G.R.A.; BATISTA, A.M.V.; GUIM, A. et al. Composição química e degradabilidade in situ da ração em ovinos em área de caatinga no sertão de Pernambuco. Revista Brasileira de Zootecnia, v.38, p.384-391, 2009

SILVA, M.G.S. Dinâmica do Crescimento e Morfoanatomia de forrageiras nativas do semiárido brasileiro. 40f. 2010. Tese (Doutorado Intregado em Zootecnia) - Universidade Federal Rural Pernambuco, Recife.

SILVA, C.M.M.S. Avaliação da camaratuba no semiárido nordestino. Petrolina: EMBRAPA-CPATSA, 1992. 22p. (Boletim de Pesquisa, 43).
SILVA, J.G.M.; SILVA, D.S.; FERREIRA, M.A. et al.. Xiquexique (Pilosocereus gounellei (A. Weber ex K. Schum.) Bly. ex Rowl.) em substituição à silagem de sorgo (Sorghum bicolor L. Moench) na alimentação de vacas leiteiras. Revista Brasileira de Zootecnia, v.34, n.4, p.1408-1417, 2005.

TEIXEIRA, F.C.P.; REINERT, F.; RUMJANEK, N.G. et al. Quantification of the contribution of biological nitrogen fixation to Cratylia mollis using the ${ }^{15} \mathrm{~N}$ natural abudance technique in the semi-arid Caatinga region of Brazil. Soil Biology \& Biochemistry, v.38, p.1989-1993, 2006.

YDOYAGA-SANTANA, D.F.; LIRA, M.A.; SANTOS, M.V.F. et al. Caracterização da caatinga e da dieta de novilhos fistulados, na época chuvosa, no semiárido de Pernambuco. Revista Brasileira de Zootecnia, 2010a. Prelo.

YDOYAGA-SANTANA, D.F.; LIRA, M.A.; SANTOS, M.V.F. et al. Consumo e desempenho de novilhas das raças Girolando e Guzerá suplementadas na caatinga, época chuvosa, no semiárido de Pernambuco, Brasil. Revista Brasileira de Zootecnia, 2010b. Prelo. 